\title{
ANALISIS PORTOFOLIO OPTIMAL DENGAN PENDEKATAN MODEL INDEKS TUNGGAL PADA SAHAM IDX30 DI BURSA EFEK INDONESIA
}

\author{
1)Triyono Adi Tristanto, 2)Destiana \\ Email: 1)aditristanto.only@gmail.com 2)destianaputri23@gmail.com \\ 1) 2)Program Studi Manajemen, Fakultas Ekonomi \\ 1) 2)Institut Bisnis dan Informatika Kosgoro 1957
}

\begin{abstract}
ABSTRAK
Tujuan penelitian ini adalah 1) Untuk mengetahui proses pembentukan portofolio optimal menggunakan perhitungan model indeks tunggal. 2) Untuk mengetahui apakah ada perbedaan saham portofolio optimal dan saham yang tidak membentuk portofolio optimal. 3) Untuk mengetahui seberapa besar proporsi dana masing-masing saham portofolio optimal yang terbentuk pada IDX30 di Bursa Efek Indonesia periode Februari 2015 sampai dengan Januari 2018. Desain penelitian ini adalah deskriptif kuantitatif. Populasi yang digunakan adalah seluruh saham yang termasuk dalam IDX30 yang berjumlah 42 saham. Teknik pemilihan sampel menggunakan purposive sampling dengan data yang jadikan sampel sebanyak 21 saham. Hasil analisis didapatkan ada 2 saham yang membentuk portofolio optimal berdasarkan Model Indeks Tunggal yaitu saham ICBP sebesar 0.02174 atau $2.17 \%$ dan saham UNTR sebesar 0.02447 atau $2.47 \%$. Saham yang dijadikan kandidat portofolio merupakan saham yang nilai Excess Return to Beta (ERB)nya lebih besar dari nilai cutt-off-point $\left(E R B \geq C^{*}\right) C^{*}=0.018300733$.

Kata kunci: Portofolio Optimal, Model Indeks Tunggal, IDX30.
\end{abstract}

\section{PENDAHULUAN}

\subsection{Latar Belakang}

Pasar modal di Indonesia beberapa tahun ini menjadi perhatian masyarakat pebisnis. Hal ini disebabkan oleh kegiatan pasar modal yang semakin berkembang dari tahun ke tahun. Seorang investor dalam melakukan investasi di pasar modal perlu pengetahuan yang cukup, pengalaman dan analisis terhadap saham yang akan dibeli, dijual, dan saham mana yang tetap dipertahankan kepemilikannya.

Investor ketika melakukan investasi tidak terlepas dari adanya fluktuasi harga saham yang dapat mempengaruhi besarnya risiko dan pengembalian. Dilihat dari besarnya tingkat keuntungan, risiko yang diperoleh di pasar modal juga lebih besar dibandingkan risiko yang diperoleh di pasar uang karena risiko yang besar akan menghasilkan keuntungan yang besar, sedangkan risiko yang kecil akan menghasilkan 
keuntungan yang kecil pula. Dalam menentukan portofolio yang optimal, seorang investor perlu melakukan analisis portofolio yang dapat memberikan keuntungan yang maksimal dan risiko terkecil.

Bagi para investor, pengetahuan terkait pembentukan portofolio merupakan pengetahuan penting dalam melakukan diversifikasi saham agar membentuk portofolio yang optimal dengan menggunakan model indeks tunggal. Dalam model indeks tunggal dapat dilakukan dengan lebih sederhana yaitu dengan menyederhanakan perhitungan model Markowitz dengan menyediakan parameter-parameter input yang dibutuhkan (Hartono, 2014 hlm.407).

Berdasarkan fenomena tersebut, menjadi menarik untuk membahas lebih lanjut tentang pembentukan dalam portofolio saham dengan judul: "Analisis Portofolio Optimal Dengan Pendekatan Model Indeks Tunggal Pada Saham IDX30 di Bursa Efek Indonesia".

\subsection{Permasalahan}

Dari Uraian latar belakang dapat dirumuskan masalah yaitu: bagaimana proses pembentukan portofolio optimal menurut perhitungan model indeks tunggal, apakah ada perbedaan antara saham yang membentuk portofolio optimal dengan saham yang tidak membentuk portofolio optimal, berapa besar proporsi masing-masing saham yang dapat membentuk portofolio optimal pada saham IDX30 di Bursa Efek Indonesia, berapa besar tingkat pengembalian yang diharapkan dan risiko dari portofolio saham IDX30 di Bursa Efek Indonesia.

\subsection{Tujuan Penelitian}

Penelitian ini bertujuan untuk mengetahui proses pembentukan portofolio optimal menurut model indeks tunggal, untuk mengetahui apakah ada perbedaan antara saham yang membentuk portofolio optimal dengan saham yang tidak membentuk portofolio optimal serta untuk mengetahui 
seberapa besar proporsi dana masing-masing saham yang membentuk portofolio optimal saham IDX30 di Bursa Efek Indonesia.

\section{TINJAUAN PUSTAKA}

Dalam melakukan investasi, tujuan utamanya adalah untuk mendapatkan keuntungan, sehingga dapat meningkatkan aset yang dimiliki. Penghasilan dari sebuah investasi mencerminkan besarnya tingkat keuntungan atau pengembalian yang diperolah dari aktivitas investasi. Dalam Investasi sektor riil, tingkat pengembaliannya tercermin pada besarnya Return On Equity (ROE) atau Return On Assets (ROA) (Warsini, 2009:4).

Besarnya pengembalian yang diperoleh dapat dilakukan dengan menghitung tingkat perbandingan atau selisih antara nilai aset (aset di akhir periode dikurangi aset di awal periode) dengan nilai aset pada awal periode.

Pasar modal merupakan kegiatan yang bersangkutan dengan penawaran umum dan perdagangan saham perusahaan publik yang berkaitan dengan saham yang diterbitkannya serta lembaga dan profesi yang berkaitan dengan saham (Undang - Undang Pasar Modal No. 8 Tahun 1995). Dalam konteks pasar modal, instrumen yang diperdagangkan dikenal dengan istilah sekuritas. Sekuritas atau biasa dikenal dengan isitlah surat berharga atau efek merupakan aset finansial yang merupakan klaim keuangan (Tandelilin, 2017:29). Instrumen efek dapat berupa saham, obligasi, bukti right, bukti waran serta produk turunan yang dikenal dengan istilah derivative (Samsul, 2015:45).

Portofolio optimal merupakan pilihan investor dari sekian banyak kumpulan portofolio efisien yang dipilih (Tandelilin, 2017:164). Untuk menentukan portofolio optimal kita harus menghitung return saham-saham individual yang telah memenuhi kriteria untuk dijadikan portofolio optimal dan selanjutnya melakukan perhitungan varian dan kovarian dari saham dan pasar yang terbentuk. 
Untuk mengukur return dan risiko sebuah saham atau portofolio, maka seorang investor perlu mengetahui single index model (Zubir, 2011:97)." Dalam model tersebut diasumsikan bahwa pergerakan return saham memiliki arah positif dengan pergerakan pasar. Jika pasar bergerak naik, dalam arti pergerakan terhadap saham meningkat, maka nilai saham di pasar akan naik juga. Sebaliknya, jika pasar bergerak turun, maka harga saham akan mengalami penurunan juga."

Single index model ini pertama kali diterbitkan pada tanggal 23 April 2012 yang mencakup 30 saham kapitalisasi terbesar di LQ45 (Hartono, 2017:163)." Pemilihan saham dilakukan setiap enam bulan, yaitu pada permulaan bulan Februari dan Agustus. Tanggal basis perhitungan adalah 30 Desember 20014 "dengan nilai perdana untuk indeks adalah 100" yang dihitung sama dengan indeks lain yaitu menggunakan rata-rata timbangan kapitalisasi pasar.

Indeks IDX30 mencakup 30 saham yang menjadi acuan portofolio yang merupakan jumlah diversifikasi aset yang ideal untuk sebuah portofolio."

\section{METODE PENELITIAN}

Penelitian ini dilakukan melalui website yaitu www.idx.co.id, https://finance.yahoo.com, www.bi.go.id dan www.bps.go.id pada Desember 2018 sampai dengan Maret 2019.

Penelitian ini menggunakan desain penelitian deskriptif kuantitatif yang bertujuan untuk memberikan gambaran secara terperinci mengenai penentuan portofolio optimal saham. Dalam penelitian ini variabel yang akan digunakan adalah portofolio optimal saham yang berjumlah 21 saham dan model indeks tunggal. Variabel tersebut kemudian diteliti dan dianalisis untuk mengetahui saham-saham IDX30 periode Februari 2015 - Januari 2018 yang dapat dijadikan kandidat portofolio. 
Dalam penelitian ini, menggunakan data kuantitatif sebagai berikut:

1) Data saham kategori indeks IDX30 dari periode Februari 2015 Januari 2018.

2) Harga saham yang telah ditutup setiap bulan dari bulan Februari 2015 - Januari 2018.

3) IHSG dan tingkat suku bunga SBI bulanan periode Februari 2015 Januari 2018.

Adapun Teknik Pengumpulan data menggunakan teknik studi kepustakaan (library research) yaitu mengumpulkan data informasi dengan membaca data-data yang berkaitan dengan objek penelitian. Sampel yang dikumpulkan menggunakan teknik purposive sampling yaitu anggota sampel ditentukan berdasarkan saham-saham yang selalu masuk dalam indeks IDX30 secara berturut-turut selama 6 (enam) periode pengamatan Februari 2015 - Januari 2018.

Dalam teknik pengolahan data dilakukan pengumpulan data, menganalisis data kemudian diolah menggunakan komputer dengan Microsoft excel 2013. Tahapan yang dilakukan dalam penelitian ini adalah:

1) Mengumpulkan data saham perusahaan

Mengumpulkan data yang menjadi sampel dalam penelitian ini, yaitu data saham penutupan (Closing Price, Data IHSG dan Data BI Rate setiap bulan.

2) Menghitung Pengembalian (Return) dan Pengembalian yang diharapkan (Expected Return) dari masing-masing saham.

Return saham adalah tingkat pengembalian yang didapat melalui sejumlah investasi pada saham.

$R_{i}=\frac{P_{t}-P_{t-1}}{P_{t-1}}$

Expected Return adalah tingkat pengembalian yang diharapkan oleh investor akan investasi yang dilakukannya.

$\mathrm{E}\left(R_{i}\right)=\frac{\sum_{t=1}^{n} R_{i t}}{n}$ 
3) Menghitung return Expected Return dari masing-masing pasar.

Return pasar adalah indeks pasar yang menjadi kriteria pasar BEI seperti Indeks Harga Saham Gabungan atau untuk saham-saham yang aktif (misalnya IDX30).

$R_{M t}=\frac{I H S G_{t}-I H S G_{t-1}}{I H S G_{t-1}}$

Expected Return pasar adalah return yang diharapkan oleh investor dapat dihasilkan oleh pasar.

$E\left(R_{m}\right)=\frac{\sum_{t=1}^{n} R_{m t}}{n}$

4) Menghitung Varian Return dari saham dan pasar

Varian digunakan untuk menghitung risiko yang mengukur adanya penyimpangan nilai yang terjadi dibandingkan dengan nilai ekspektasinya.

Varians Return Saham $=\sigma_{i^{2}}=\sum_{t-1}^{n} \frac{\left[R_{i}-E\left(R_{i}\right)\right]^{2}}{n-1}$

Varians Return Pasar $=\sigma_{m^{2}}=\sum_{t-1}^{n} \frac{\left[R_{m}-E\left(R_{m}\right)\right]^{2}}{n-1}$

5) Menghitung Standar Deviasi Saham Serta Pasar

Standar Deviasi juga digunakan untuk menghitung risiko yang mengukur adanya penyimpangan nilai yang terjadi dengan nilai ekspektasinya. Standar deviasi merupakan akar kuadrat dari varians.

Standar Deviasi Saham $=\sigma i=\sqrt{\sigma_{i^{2}}}$

Standar Deviasi Pasar $=\sigma m=\sqrt{\sigma_{m^{2}}}$

6) Menghitung Beta dan Alpha masing-masing saham.

Beta merupakan koefisien yang digunakan untuk mengukur pengaruh return pasar terhadap perubahan yang telah terjadi pada return saham.

$\beta_{i}=\frac{\sigma_{i M}}{\sigma_{M^{2}}}$

Alpha merupakan variabel yang tidak dapat dipengaruhi oleh return pasar.

$\alpha_{i}=E\left(R_{i}\right)-\beta_{i} \cdot E\left(R_{m}\right)$ 
7) Menghitung Varians Error Residual

Varians Error Residual atau Varian kesalahan residu merupakan variabel yang mengindikasikan besarnya risiko yang tidak sistematis dan unik yang biasanya terjadi di perusahaan.

$\sigma_{e i^{2}}=\frac{i}{t} \sum_{t=1}^{t}\left[R_{i t}-\left(\alpha_{i}+\beta_{i} \cdot R_{m t}\right)\right]^{2}$

8) Menentukan portofolio optimal berdasarkan model indeks tunggal.

a. Menghitung nilai Excess Return To Beta (ERB) dari setiap saham

$E R B=\frac{E(R i)-R_{B R}}{\beta i}$

b. Mengurutkan level saham menurut nilai Excess Return To Beta (ERB) dari yang tertinggi sampai yang terendah.

c. Menghitung Cut Off Rate (Ci)

Merupakan ukuran yang digunakan sebagai titik pembatas untuk menentukan suatu saham dapat dikategorikan ke dalam portofolio atau tidak. Perhitungan $\mathrm{Ci}$ dapat dilakukan dengan terlebih dahulu menghitung nilai $A_{i}$ dan $B_{i}$ untuk masing-masing sekuritas ke i.

$A_{i}=\frac{\left[E\left(R_{i}\right)-R_{B R}\right] x \beta_{i}}{\sigma_{e i^{2}}}$ dan $B_{i}=\frac{\beta_{i^{2}}}{\sigma_{e i^{2}}}$

Setelah mendapatkan nilai $A_{i}$ dan $B_{i}$ selanjutnya mencari nilai $C_{i}$ $C i=\frac{\sigma m^{2} \sum_{j=1}^{i} A_{j}}{1+\sigma m^{2} \sum_{j=1}^{i} B_{j}}$

d. Menentukan kandidat portofolio dengan kriteria $E R B>C^{*}$.

e. Menentukan proporsi (Wi) setiap saham dalam portofolio optimal.

$Z_{i}=\frac{\beta_{i}}{\sigma_{e i^{2}}}\left(E R B_{i}-C^{*}\right)$

Dengan nilai $Z_{i}$ adalah sebesar:

$W i=\frac{Z i}{\sum_{j=1}^{k} Z_{j}}$ 
9) Menghitung Expected Return Portofolio $E\left(R_{p}\right)$ dan $\left(\sigma_{p^{2}}\right)$

Perhitungan ini digunakan untuk mengukur risiko portofolio. Expected Return Portofolio adalah rata-rata tertimbang dari return individual dari setiap saham yang membentuk portofolio.

$E\left(R_{P}\right)=\alpha_{P}+\beta_{P} . E\left(R_{m}\right)$

Alpha dan beta portofolio dapat dicari dengan rumus:

$\alpha_{p}=\sum_{i=1}^{n} W_{i} \cdot \alpha_{i}$ dan $\beta_{p}=\sum_{i}^{n} W_{i} \cdot \beta_{i}$

sedangkan risiko menggunakan rumus sebagai berikut:

$\sigma p^{2}=\beta_{p^{2}} \cdot \sigma_{m^{2}}+\left(\sum_{i=1}^{n} W_{i^{2}} \cdot \sigma_{e i^{2}}\right)$

\section{HASIL PENELITIAN DAN PEMBAHASAN}

Dalam penelitian ini, objek yang digunakan adalah perusahaan yang terdaftar di IDX30 Bursa Efek Indonesia yang terdiri dari 30 saham yang merupakan konstituen dari Indeks LQ45. Terdapat 21 perusahaan sebagai objek penelitian yang memenuhi kriteria sebagai sampel penelitian dari 30 perusahaan yang tergabung ke dalam Indeks IDX30 periode Februari 2015 - Januari 2018. Daftar saham IDX30 yang masuk 6 periode berturut-turut:

\begin{tabular}{ccl}
\hline NO & KODE SAHAM & \multicolumn{1}{c}{ NAMA SAHAM } \\
\hline 1 & ADHI & Adhi Karya (Persero) Tbk \\
\hline 2 & ADRO & Adaro Energy Tbk \\
\hline 3 & ASII & Astra International Tbk \\
\hline 4 & BBCA & Bank Central Asia Tbk \\
\hline 5 & BBNI & Bank Negara Indonesia (Persero) Tbk \\
\hline 6 & BBRI & Bank Rakyat Indonesia (Persero) Tbk \\
\hline 7 & BMRI & Bank Mandiri (Persero) Tbk \\
\hline 8 & GGRM & Gudang Garam Tbk \\
\hline 9 & ICBP & Indofood CBP Sukses Makmur Tbk \\
\hline 10 & INDF & Indofood Sukses Makmur Tbk \\
\hline 11 & INTP & Indocement Tunggal Prakasa Tbk \\
\hline 12 & KLBF & Kalbe Farma Tbk \\
\hline 13 & LPKR & Lippo Karawaci Tbk \\
\hline 14 & LPPF & Matahari Department Store Tbk \\
\hline 15 & MNCN & Media Nusantara Citra Tbk \\
\hline 16 & PGAS & Perusahaan Gas Negara (Persero) Tbk \\
\hline 17 & SMGR & Semen Indonesia (Persero) Tbk \\
\hline
\end{tabular}




\begin{tabular}{lll}
\hline 18 & SSMS & Sawit Sumbermas Sarana Tbk \\
\hline 19 & TLKM & Telekomunikasi Indonesia (Persero) Tbk \\
\hline 20 & UNTR & United Tractors Tbk \\
\hline 21 & UNVR & Unilever Indonesia Tbk \\
\hline
\end{tabular}

Analisis pembentukan portofolio optimal dengan model indeks tunggal dapat dilakukan dengan langkah sebagai berikut:

1) Data IHSG \& BI Rate

Data IHSG Periode Februari 2015 - Januari 2018

\begin{tabular}{lcccc}
\hline \multirow{2}{*}{ BULAN } & \multicolumn{5}{c}{ TAHUN } \\
\cline { 2 - 5 } & $\mathbf{2 0 1 5}$ & $\mathbf{2 0 1 6}$ & $\mathbf{2 0 1 7}$ & $\mathbf{2 0 1 8}$ \\
\hline Januari & \multicolumn{1}{c}{ - } & 4615.163 & 5294.103 & 6605.631 \\
\hline Februari & 5450.294 & 4770.956 & 5386.692 & - \\
\hline Maret & 5518.675 & 4845.371 & 5568.106 & - \\
\hline April & 5086.425 & 4838.583 & 5685.298 & - \\
\hline Mei & 5216.379 & 4796.869 & 5738.155 & - \\
\hline Juni & 4910.658 & 5016.647 & 5829.708 & - \\
\hline Juli & 4802.529 & 5215.994 & 5840.939 & - \\
\hline Agustus & 4509.607 & 5386.082 & 5864.059 & - \\
\hline September & 4223.908 & 5364.804 & 5900.854 & - \\
\hline Oktober & 4455.18 & 5422.542 & 6005.784 & - \\
\hline November & 4446.458 & 5148.91 & 5952.138 & - \\
\hline Desember & 4593.008 & 5296.711 & 6355.654 & - \\
\hline
\end{tabular}

Data BI Rate Februari 2015 - Januari 2018

\begin{tabular}{lcccc}
\hline \multirow{2}{*}{ BULAN } & \multicolumn{4}{c}{ TAHUN } \\
\cline { 2 - 5 } & $\mathbf{2 0 1 5}$ & $\mathbf{2 0 1 6}$ & $\mathbf{2 0 1 7}$ & $\mathbf{2 0 1 8}$ \\
\hline Januari & - & $7.25 \%$ & $4.75 \%$ & $4.25 \%$ \\
\hline Februari & $7.50 \%$ & $7.00 \%$ & $4.75 \%$ & - \\
\hline Maret & $7.50 \%$ & $6.75 \%$ & $4.75 \%$ & - \\
\hline April & $7.50 \%$ & $6.75 \%$ & $4.75 \%$ & - \\
\hline Mei & $7.50 \%$ & $6.75 \%$ & $4.75 \%$ & - \\
\hline Juni & $7.50 \%$ & $6.50 \%$ & $4.75 \%$ & - \\
\hline Juli & $7.50 \%$ & $6.50 \%$ & $4.75 \%$ & - \\
\hline Agustus & $7.50 \%$ & $5.25 \%$ & $4.50 \%$ & - \\
\hline September & $7.50 \%$ & $5.00 \%$ & $4.25 \%$ & - \\
\hline Oktober & $7.50 \%$ & $4.75 \%$ & $4.25 \%$ & - \\
\hline November & $7.50 \%$ & $4.75 \%$ & $4.25 \%$ & - \\
\hline Desember & $7.50 \%$ & $4.75 \%$ & $4.25 \%$ & - \\
\hline
\end{tabular}


2) Return Saham $\left(R_{i}\right)$ dan Expected Return Saham $\mathrm{E}\left(R_{i}\right)$

Dalam penelitian ini Return Saham ditentukan berdasarkan Indeks Harga Saham Gabungan (IHSG) untuk mendapatkan Return Saham.

\begin{tabular}{clcc}
\hline NO & KODE SAHAM & $\boldsymbol{R E T U R \boldsymbol { N }}\left(\boldsymbol{R}_{\boldsymbol{i}}\right)$ & EXPECTED RETURN $\boldsymbol{E}\left(\boldsymbol{R}_{\boldsymbol{i}}\right)$ \\
\hline 1 & ADHI & -0.16965 & -0.00471 \\
\hline 2 & ADRO & 1.13689 & 0.03158 \\
\hline 3 & ASII & 0.17060 & 0.00474 \\
\hline 4 & BBCA & 0.57325 & 0.01592 \\
\hline 5 & BBNI & 0.55044 & 0.01529 \\
\hline 6 & BBRI & 0.56705 & 0.01575 \\
\hline 7 & BMRI & 0.47193 & 0.01311 \\
\hline 8 & GGRM & 0.41540 & 0.01154 \\
\hline 9 & ICBP & 0.78280 & 0.02174 \\
\hline 10 & INDF & 0.12340 & 0.00343 \\
\hline 11 & INTP & 0.08869 & 0.00246 \\
\hline 12 & KLBF & -0.04529 & -0.00126 \\
\hline 13 & LPKR & -0.55287 & -0.01536 \\
\hline 14 & LPPF & -0.16973 & -0.00471 \\
\hline 15 & MNCN & -0.22984 & -0.00638 \\
\hline 16 & PGAS & -0.30030 & -0.00834 \\
\hline 17 & SMGR & -0.17495 & -0.00486 \\
\hline 18 & SSMS & 0.09173 & 0.00255 \\
\hline 19 & TLKM & 0.40634 & 0.01129 \\
\hline 20 & UNTR & 0.88084 & 0.02447 \\
\hline 21 & UNVR & 0.44568 & 0.01238 \\
\hline
\end{tabular}

Menunjukkan adanya Return saham positif dan negatif, return saham positif mengindikasikan adanya kenaikan harga saham pada periode tersebut, sedangkan untuk return negatif mengindikasikan adanya penurunan harga saham pada periode tersebut. Expected Return merupakan pengembalian saham yang diharapkan oleh investor.

3) Return Pasar $\left(R_{M}\right)$ dan Expected Return Pasar $E\left(R_{M}\right)$.

\begin{tabular}{lll}
\hline \multicolumn{1}{c}{ PERIODE } & IHSG & $\boldsymbol{R}_{\boldsymbol{m}}$ \\
\hline Januari 2015 & 5289.404 & - \\
\hline Februari 2015 & 5450.294 & 0.030417 \\
\hline Maret 2015 & 5518.675 & 0.012546 \\
\hline April 2015 & 5086.425 & -0.07832 \\
\hline Mei 2015 & 5216.379 & 0.025549 \\
\hline Juni 2015 & 4910.658 & -0.05861 \\
\hline Juli 2015 & 4802.529 & -0.02202 \\
\hline Agustus 2015 & 4509.607 & -0.06099 \\
\hline September 2015 & 4223.908 & -0.06335 \\
\hline
\end{tabular}




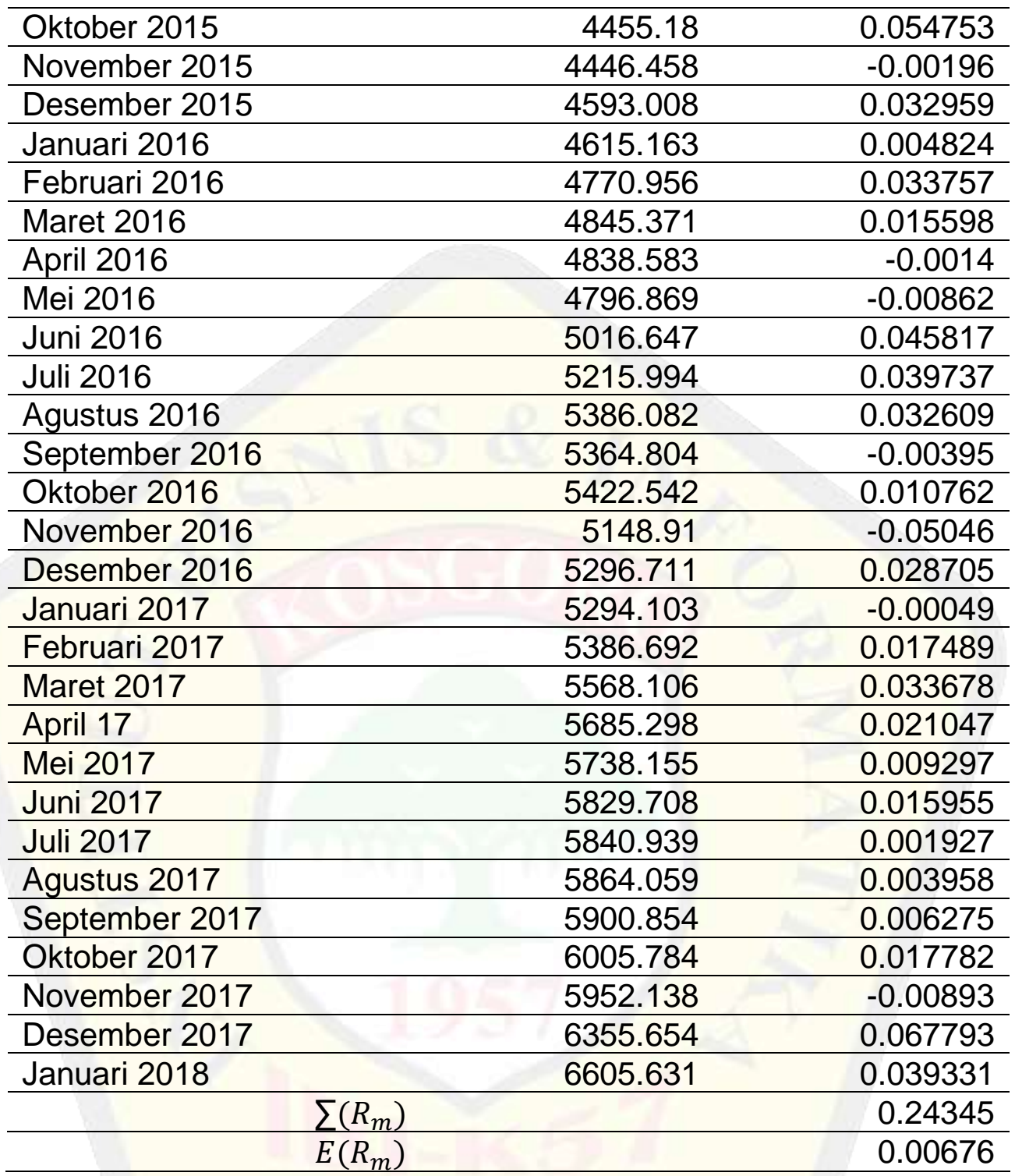

Dari perhitungan di atas diperoleh tingkat Return pasar yang positif sebesar 0.00676 atau $6,76 \%$.

4) Variance, Standar Deviasi dan Kovarian Saham \& Pasar

\begin{tabular}{clccc}
\hline NO & KODE & VARIANCE SAHAM $\left(\boldsymbol{\Sigma} \mathbf{I}^{2}\right)$ & $\begin{array}{c}\text { STANDAR DEVIASI } \\
\text { SAHAM }(\boldsymbol{\Sigma} \mathbf{)})\end{array}$ & $\begin{array}{c}\text { KOVARIAN } \\
\text { SAHAM }\end{array}$ \\
\hline 1 & ADHI & 0.00946 & 0.09728 & 0.00123 \\
\hline 2 & ADRO & 0.01350 & 0.11618 & 0.00209 \\
\hline 3 & ASII & 0.00488 & 0.06983 & 0.00190 \\
\hline 4 & BBCA & 0.00219 & 0.04677 & 0.00124 \\
\hline 5 & BBNI & 0.00757 & 0.08698 & 0.00209 \\
\hline 6 & BBRI & 0.00572 & 0.07561 & 0.00185 \\
\hline 7 & BMRI & 0.00419 & 0.06474 & 0.00174 \\
\hline 8 & GGRM & 0.00430 & 0.06555 & 0.00060 \\
\hline 9 & ICBP & 0.04119 & 0.20294 & 0.00009 \\
\hline
\end{tabular}




\begin{tabular}{rllll}
\hline 10 & INDF & 0.00548 & 0.07401 & 0.00132 \\
\hline 11 & INTP & 0.00797 & 0.08928 & 0.00162 \\
\hline 12 & KLBF & 0.00365 & 0.06039 & 0.00127 \\
\hline 13 & LPKR & 0.00900 & 0.09487 & 0.00087 \\
\hline 14 & LPPF & 0.00898 & 0.09474 & 0.00116 \\
\hline 15 & MNCN & 0.02299 & 0.15162 & 0.00217 \\
\hline 16 & PGAS & 0.02136 & 0.14616 & 0.00228 \\
\hline 17 & SMGR & 0.00499 & 0.07067 & 0.00142 \\
\hline 18 & SSMS & 0.01093 & 0.07067 & 0.00170 \\
\hline 19 & TLKM & 0.00332 & 0.05758 & 0.00080 \\
\hline 20 & UNTR & 0.00560 & 0.07483 & 0.00108 \\
\hline 21 & UNVR & 0.00313 & 0.05594 & 0.00063 \\
\hline & & & & \\
\hline
\end{tabular}

5) Perhitungan Return Bebas Risiko (Risk Free)

\begin{tabular}{lccr}
\hline \multirow{2}{*}{ BULAN } & \multicolumn{3}{c}{ TAHUN } \\
\cline { 2 - 4 } & $\mathbf{2 0 1 5}$ & $\mathbf{2 0 1 6}$ & $\mathbf{2 0 1 7}$ \\
\hline Februari & 0.00625 & 0.0058333 & 0.0039583 \\
\hline Maret & 0.00625 & 0.005625 & 0.0039583 \\
\hline April & 0.00625 & 0.005625 & 0.0039583 \\
\hline Mei & 0.00625 & 0.005625 & 0.0039583 \\
\hline Juni & 0.00625 & 0.0054167 & 0.0039583 \\
\hline Juli & 0.00625 & 0.0054167 & 0.0039583 \\
\hline Agustus & 0.00625 & 0.004375 & 0.00375 \\
\hline September & 0.00625 & 0.0041667 & 0.0035417 \\
\hline Oktober & 0.00625 & 0.0039583 & 0.0035417 \\
\hline November & 0.00625 & 0.0039583 & 0.0035417 \\
\hline Desember & 0.00625 & 0.0039583 & 0.0035417 \\
\hline Januari & 0.0060417 & 0.0039583 & 0.0035417 \\
\hline Jumlah & & $\mathbf{0 . 1 7 7 9 1 6 6 6 7}$ & \\
\hline RF/Bulan & & $\mathbf{0 . 0 0 4 9 4 2 1 3}$ & \\
\hline
\end{tabular}

Tabel tersebut menggambarkan bahwa apabila seorang investor melakukan investasi pada SBI, maka keuntungan yang diharapkan investor tersebut sebesar $0,049 \%$ per bulan dengan risiko $0 \%$.

6) Beta ( $\beta)$, Alpha $(\alpha)$, dan Variance Error Residual $\left(\sigma_{e i^{2}}\right)$.

Untuk menghitung alpha, beta dan variance error residual masingmasing saham menggunakan program Ms. Excel. Beta dihitung dengan rumus slope. Alpha dihitung menggunakan rumus intercept. Variance error merupakan risiko unik atau unsystematic risk suatu saham.

\begin{tabular}{ccccc}
\hline NO & KODE SAHAM & $\boldsymbol{\beta}_{\mathbf{i}}$ & $\boldsymbol{\alpha}_{\mathbf{i}}$ & $\boldsymbol{\sigma}_{\mathrm{ei}^{2}}$ \\
\hline 1 & ADHI & 1.09091 & -0.01209 & 0.01080 \\
\hline
\end{tabular}




\begin{tabular}{clrrr}
\hline 2 & ADRO & 1.85491 & 0.01904 & 0.01737 \\
\hline 3 & ASII & 1.69156 & -0.00670 & 0.00810 \\
\hline 4 & BBCA & 1.10449 & 0.00845 & 0.00356 \\
\hline 5 & BBNI & 1.85500 & 0.00275 & 0.01144 \\
\hline 6 & BBRI & 1.64708 & 0.00461 & 0.00877 \\
\hline 7 & BMRI & 1.54944 & 0.00263 & 0.00689 \\
\hline 8 & GGRM & 0.53286 & 0.00794 & 0.00462 \\
\hline 9 & ICBP & 0.08213 & 0.02119 & 0.04119 \\
\hline 10 & INDF & 1.17110 & -0.00449 & 0.00702 \\
\hline 11 & INTP & 1.43786 & -0.00726 & 0.01030 \\
\hline 12 & KLBF & 1.13065 & -0.00890 & 0.00509 \\
\hline 13 & LPKR & 0.77108 & -0.02057 & 0.00967 \\
\hline 14 & LPPF & 1.03422 & -0.01171 & 0.01018 \\
\hline 15 & MNCN & 1.93230 & -0.01945 & 0.02719 \\
\hline 16 & PGAS & 2.02999 & -0.02207 & 0.02600 \\
\hline 17 & SMGR & 1.26288 & -0.01340 & 0.00679 \\
\hline 18 & SSMS & 1.51135 & -0.00767 & 0.01350 \\
\hline 19 & TLKM & 0.71260 & 0.00647 & 0.00389 \\
\hline 20 & UNTR & 0.96091 & 0.01797 & 0.00664 \\
\hline 21 & UNVR & 0.56088 & 0.00859 & 0.00348 \\
\hline & & & & \\
\hline
\end{tabular}

Berdasarkan tabel di atas menunjukkan bahwa alpha bervariatif, nilai alpha dapat negatif dan positif yang terjadi pada perusahaan. Alpha adalah nilai expected return saham yang tidak terikat terhadap tingkat pengembalian pasar. Beta adalah risiko unik dari saham, beta merupakan sensifitas return saham terhadap return pasar. Beta positif berarti jika return pasar mengalami peningkatan, maka return saham juga akan meningkat. Besarnya koefisien beta normal yaitu satu, bila beta kurang dari satu disebut saham defensif, sedangkan apabila tingkat beta lebih besar dari satu disebut saham agresif.

7) Penentuan Portofolio Optimal Sesuai Model Indeks Tunggal.

a. Excess Return to Beta (ERB) Cut off Rate (Ci) dan Cut off Point $\left(C^{\star}\right)$.

Cut off Rate $\left(\mathrm{C}_{\mathrm{i}}\right)$ merupakan suatu ukuran dalam menentukan titik pembatas dimana suatu saham dapat dikategorikan sebagai portofolio atau tidak. Perhitungan $\mathrm{Ci}$ terlebih dahulu dapat 
dilakukan dengan menghitung setiap sekuritas dengan nilai $\mathrm{Ai}$ dan $\mathrm{Bi}$.

\begin{tabular}{|c|c|c|c|c|c|c|}
\hline NO & $\begin{array}{l}\text { KODE } \\
\text { SAHAM }\end{array}$ & $\mathrm{ERB}_{\mathrm{i}}$ & $A_{i}$ & $B_{i}$ & $C_{i}$ & $C^{\star}$ \\
\hline 1 & $\mathrm{ADHI}$ & -0.00885 & -0.97492 & 110.16163 & 0.0028520386 & \\
\hline 2 & ADRO & 0.01436 & 2.84476 & 198.09063 & 0.0160982270 & \\
\hline 3 & ASII & -0.00012 & -0.04245 & 353.44374 & 0.0076713379 & \\
\hline 4 & BBCA & 0.00994 & 3.40717 & 342.68367 & 0.0130419116 & \\
\hline 5 & BBNI & 0.00558 & 1.67814 & 300.82777 & 0.0100286658 & \\
\hline 6 & BBRI & 0.00656 & 2.03004 & 309.32739 & 0.0110674124 & \\
\hline 7 & BMRI & 0.00527 & 1.67814 & 348.26198 & 0.0084920701 & \\
\hline 8 & GGRM & 0.01238 & 0.76143 & 61.50377 & 0.0151402198 & \\
\hline 9 & ICBP & 0.20457 & 0.03350 & 0.16377 & 0.0019504426 & \\
\hline 10 & INDF & -0.00129 & -0.25262 & 195.36278 & 0.0069670707 & \\
\hline 11 & INTP & -0.00172 & -0.34611 & 200.78249 & 0.0054425741 & \\
\hline 12 & KLBF & -0.00548 & -1.37844 & 251.37106 & 0.0049331805 & \\
\hline 13 & LPKR & -0.02633 & -1.61883 & 61.49105 & 0.0020667254 & \\
\hline 14 & LPPF & -0.00934 & -0.98105 & 105.06725 & 0.0025197351 & \\
\hline 15 & MNCN & -0.00586 & -0.80490 & 137.31658 & 0.0044764342 & \\
\hline 16 & PGAS & -0.00654 & -1.03713 & 158.49002 & 0.0039633127 & \\
\hline 17 & SMGR & -0.00776 & -1.82347 & 234.93523 & 0.0032063064 & \\
\hline 18 & SSMS & -0.00158 & -0.26799 & 169.18342 & 0.0064223579 & \\
\hline 19 & TLKM & 0.00890 & 1.16333 & 130.65017 & 0.0124899929 & \\
\hline 20 & UNTR & 0.02032 & 2.82603 & 139.07579 & 0.0183007332 & 0.0183007332 \\
\hline 21 & UNVR & 0.01326 & 1.19768 & 90.31512 & 0.0155219781 & \\
\hline
\end{tabular}

Saham yang memiliki kategori portofolio adalah saham yang mempunyai Excess Return To Beta lebih besar atau sama seperti Cut-off-Point yang dihasilkan.

b. Penentuan Kandidat Portofolio Optimal

Portofolio optimal ditentukan dengan kriteria $E R B \geq C^{*}$ yaitu mengurutkan ERB yang paling besar sampai ERB paling kecil.

Kandidat Saham Indeks IDX30 dalam Portofolio Optimal

\begin{tabular}{ccccc}
\hline NO & NAMA SAHAM & ERB $_{\mathbf{i}}$ & $\mathbf{C}^{*}$ & KETERANGAN \\
\hline 1 & ICBP & 0.20457 & 0.0183007332 & OPTIMAL \\
\hline 2 & UNTR & 0.02032 & 0.0183007332 & OPTIMAL \\
\hline 3 & ADRO & 0.01436 & 0.0183007332 & - \\
\hline 4 & UNVR & 0.01326 & 0.0183007332 & - \\
\hline 5 & GGRM & 0.01238 & 0.0183007332 & - \\
\hline 6 & BBCA & 0.00994 & 0.0183007332 & - \\
\hline 7 & TLKM & 0.00890 & 0.0183007332 & - \\
\hline 8 & BBRI & 0.00656 & 0.0183007332 & - \\
\hline 9 & BBNI & 0.00558 & 0.0183007332 & - \\
\hline 10 & BMRI & 0.00527 & 0.0183007332 & - \\
\hline 11 & ASII & -0.00012 & 0.0183007332 & - \\
\hline 12 & INDF & -0.00129 & 0.0183007332 & - \\
\hline 13 & SSMS & -0.00158 & 0.0183007332 & - \\
\hline 14 & INTP & -0.00172 & 0.0183007332 & - \\
\hline 15 & KLBF & -0.00548 & 0.0183007332 & - \\
\hline 16 & MNCN & -0.00586 & 0.0183007332 & - \\
\hline
\end{tabular}




\begin{tabular}{lllll}
\hline 17 & PGAS & -0.00654 & 0.0183007332 & - \\
\hline 18 & SMGR & -0.00776 & 0.0183007332 & - \\
\hline 19 & ADHI & -0.00885 & 0.0183007332 & - \\
\hline 20 & LPPF & -0.00934 & 0.0183007332 & - \\
\hline 21 & LPKR & -0.02633 & 0.0183007332 & - \\
\hline
\end{tabular}

Berdasarkan perhitungan sebelumnya diketahui bahwa terdapat 2 saham dari 21 saham yang masuk kategori portofolio optimal yang menurut hasil perbandingan antara ERB dan $\mathrm{C}_{\mathrm{i}}$.

c. Proporsi Masing-masing Saham kategori Portofolio Optimal

\begin{tabular}{ccccc}
\hline NO & NAMA SAHAM & $\mathbf{Z}_{\mathbf{i}}$ & $\mathbf{W}_{\mathbf{i}}$ & PERSENTASE \\
\hline 1 & ICBP & 0.371401073 & 0.559619661 & $56 \%$ \\
\hline 2 & UNTR & 0.292265876 & 0.440380339 & $44 \%$ \\
\hline & Total & $\mathbf{0 . 6 6 3 6 6 6 9 4 9}$ & $\mathbf{1 . 0 0 0 0 0 0 0 0 0}$ & $\mathbf{1 0 0 \%}$ \\
\hline
\end{tabular}

Sumber : Hasil Penelitian, (Data Diolah)

d. Expected Return dan Risiko dari Kandidat Saham Portofolio Optimal.

Return ekspektasi portofolio merupakan hasil rata-rata tertimbang dari tingkat pengembalian yang diharapkan oleh masing-masing sekuritas di dalam portofolio (Hartono, 2010:254).

\section{Expected Return portofolio pada saham IDX30}

\begin{tabular}{|c|c|c|c|c|c|c|}
\hline $\begin{array}{l}\text { NAMA } \\
\text { SAHAM }\end{array}$ & $A_{i}$ & $B_{i}$ & $\mathbf{W}_{\mathrm{i}}$ & E(RM) & AP & BP \\
\hline ICBP & 0.02119 & 0.08213 & 0.559619661 & 0.00676 & 0.011858 & 0.045964 \\
\hline UNTR & 0.01797 & 0.96091 & 0.440380339 & 0.00676 & 0.007914 & 0.423166 \\
\hline & Total & & 1 & & 0.019771 & 0.469130 \\
\hline
\end{tabular}

Langkah selanjutnya, menghitung risiko portofolio disajikan pada tabel sebagai berikut.

Risiko portofolio pada saham IDX30

\begin{tabular}{|c|c|c|c|c|c|}
\hline $\begin{array}{l}\text { NAMA } \\
\text { SAHAM }\end{array}$ & $\beta_{e^{2}}$ & $\sigma m^{2}$ & $\mathbf{W i}^{2}$ & $\sigma_{\mathrm{ei}}{ }^{2}$ & $\sum \mathrm{Wi}^{2} \cdot \sigma_{\mathrm{ei}}{ }^{2}$ \\
\hline ICBP & 0.22008315 & 0.00000127 & 0.313174165 & 0.04119 & 0.012900574 \\
\hline UNTR & 0.22008315 & 0.00000127 & 0.193934843 & 0.00664 & 0.001287569 \\
\hline & & & & Total & 0.014188143 \\
\hline \multicolumn{3}{|c|}{ Varians Portofolio } & 0.01419 & & \\
\hline \multicolumn{3}{|c|}{ Risiko Portofolio } & $1,41 \%$ & & \\
\hline
\end{tabular}

Berdasarkan tabel di atas, diperoleh varians portofolio sebesar 0.021419 , dengan risiko portofolio sebesar $1,49 \%$. 


\section{PENUTUP}

\subsection{Kesimpulan}

Berdasarkan hasil pembahasan dan analisis dari penentuan portofolio optimal sesuai kriteria Model Indeks Tunggal pada saham IDX30 yang diperoleh dari Bursa Efek Indonesia periode Februari 2015 sampai dengan Januari 2018 dapat disimpulkan sebagai berikut :

1) Setelah dilakukan analisis portofolio optimal menggunakan kriteria model indeks tunggal pada saham IDX30 periode Februari 2015 Januari 2018 dari 21 perusahaan yang dijadikan sampel, menunjukkan hanya mampu menghasilkan 2 saham yang dikategorikan memiliki kriteria portofolio dan 19 saham perusahaan yang tidak dapat dijadikan portofolio. Saham yang dijadikan kandidat portofolio adalah saham yang perolehan Excess Return To Beta (ERB) lebih besar dari nilai Cut-Off-Point $\left(E R B \geq C^{*}\right)\left(C^{*}=\right.$ 0.0183007332). Dua perusahaan yang dijadikan kandidat portofolio adalah PT Indofood CBP Sukses Makmur Tbk (ICBP) dengan ERB sebesar 0.020457 dan PT United Tractors Tbk (UNTR) dengan ERB sebesar 0.02032 .

2) Proporsi besarnya dana yang dialokasikan untuk setiap saham yang memiliki kategori portofolio optimal sesuai Model Indeks Tunggal yaitu saham ICBP dengan proporsi $55,96 \%$ dan UNTR dengan proporsi $44,04 \%$.

\subsection{Saran}

Untuk investor dan calon investor, agar memilih jenis saham yang memiliki kriteria portofolio optimal dan mempertimbangkan nilai ERB dan $\mathrm{Ci}$ serta memperhatikan volume perdagangan sebagai indikator utama investasi. 


\section{DAFTAR PUSTAKA}

Fahmi, Irham dan Yovi Lavianti Hadi (2009). Teori Portofolio dan Analisis Investasi. Bandung: Alfabeta.

Hadi, N. (2013). Pasar Modal: Acuan Teoritis dan Praktis Investasi di Instrumen Keuangan Pasar Modal. Yogyakarta: Graha Ilmu.

Halim, Abdul. (2014). Analisis Investasi. Edisi Kedua. Jakarta : Salemba Empat.

Hartono, Jogiyanto. (2010). Teori Portofolio dan Analisis Investasi. Edisi Ketujuh. Yogyakarta : BPFE.

Hartono, Jogiyanto. (2014). Teori Portofolio dan AnalisisInvestasi. Edisi Kesembilan . Yogyakarta: BPFE.

Hartono, Jogiyanto. (2017). Teori Portofolio dan AnalisisInvestasi. Edisi Kesebelas . Yogyakarta: BPFE.

Husnan, Suad. (2009). Dasar - dasar Teori Portofolio dan Analisis Sekuritas. Edisi keempat. Makasar: STIE YKPN.

Nur, Andri P. dan Sumiarti (2016). Metodologi Penelitian. Bogor: IPB Press.

Samsul, Mohammad. (2005). Pasar Modal dan Manajemen Portofolio. Jakarta: Erlangga.

Samsul, Mohammad. (2015). Pasar Modal dan Manajemen Portofolio. Edisi kedua. Jakarta: Erlangga.

Sobana, Dadang Husen. (2017). Studi Kelayakan Bisnis. Bandung: Pustaka Setia.

Suroto, 2015; Analisis Portofolio Menurut Model Indeks Tunggal (Studi Empiris Pada Saham LQ-45 Di BEI Periode Agustus 2012 - Juli 2015). Jurnal. Semarang : Universitas 17 Agustus 1945.

Syahyunan, (2015). Manajemen Keuangan I. Edisi ketiga, Medan: USU press.

Tandelilin, Eduardus. (2010). Portofolio dan Investasi. Edisi Pertama. Yogyakarta: Kanisius.

Tandelilin, Eduardus. (2017). Pasar modal Manajemen Portofolio dan Investasi. Yogyakarta: Kanisius.

Warsini, Sabar (2009) Manajemen Investasi. Jakarta :Semesta Media.

Zubir, Z. (2011). Manajemen Portofolio: Penerapannya dalam Investasi Saham. Jakarta: Salemba Empat..

http://www.idx.co.id/data-pasar/data-saham/indeks-saham/ 